\title{
Functional and Morphological Evaluation of the Mucosa of Endometrium and Oviduct in Postpartum Goats
}

\author{
M. KRAJNIČÁKOVÁ, V. CIGÁNKOVÁ르, L'. LENHARDT ${ }^{1}$, M. KOSTECKÝ, I. MARAČEK \\ Research Institute of Veterinary Medicine, University of Veterinary Medicine, Košice \\ ${ }^{1}$ University of Veterinary Medicine, Košice
}

Received July 15, 2002

Accepted November 18, 2002

\begin{abstract}
Krajničáková M., V. Cigánková, L. Lenhardt, M. Kostecký, I. Maraček: Functional and Morphological Evaluation of the Mucosa of Endometrium and Oviduct in Postpartum Goats. Acta Vet. Brno 2002, 71: 517-522.

The aim of this work was to characterize the structural changes in the surface epithelium and endometrial glands as well as oviduct mucosa in goats after parturition using the light and transmission electron microscopy. Fifteen Slovak short-haired goats were used. They were killed on days 3, 21, 36, and 40 after parturition. The evaluation of semithin sections from day 3 postpartum revealed impaired epithelial cells. Lymphocytes and neutrophil granulocytes were present in the lumen of uterine glands. Ciliated cells and sporadic secretory cells that were released into the oviduct lumen were found on semithin sections from the ampullary part of oviducts (day 3 postpartum). Cells in the cytoplasm contained mitochondria and cisternae of endoplasmic reticulum. Impaired cells with a vacuolised cytoplasm were present on ultrathin sections from the caruncular region of endometrium on day 21 postpartum. Uterine glands were in the stage of proliferation. Ultrathin sections from day 21 postpartum showed that ciliated cells were present and secretory cells with secretory granules increased in the epithelium of oviduct ampulla. The surface epithelium on day 36 was continuous, simple columnar; in some locations pseudostratified columnar. No signs of morphological damage of cells were found. On the free border of ciliated cells of the oviduct mucosa on day 36 , the presence of numerous kinocilia was observed. Glandular cells contained a great amount of dense secretory granules in the cytoplasm (day 36 postpartum). The microscopic and submicroscopic appearance of the uterus and oviduct on day 40 postpartum was similar to that on day 36 of the period observed. The results obtained can be used in synchronization or induction of estrus in the intensification of reproduction and increasing the reproductive turnover in goat husbandry.
\end{abstract}

Goat, uterus, oviduct, puerperium, light and electron microscopy

Morphological changes in the uterus during puerperium are an important and limiting factor from the point of view of further ability of females to conceive. The uterus enlarged due to previous pregnancy undergoes the involution processes and regressive changes that include regeneration processes of endometrium. Studies of the postparturient involution of the sheep uterus with its completion between day 28 and 34 were reported by $\mathrm{V}$ an Wyk et al. (1971), Botha (1976), Krajničáková et al. (1999). Studies of the involution of the goat uterus are scarce (Lyngset 1968; Srivastava and Pandey 1982; Greyling and Van Niekerk 1991). Greyling and Van Niekerk (1991) recorded that the involution processes in the uterus of Boer goats was completed by day 28 postpartum. Observations of the reproductive apparatus in goats during puerperium in our conditions are not available.

Histological and functional changes in the oviduct from the point of view of its role in the fertilisation and fertility disorders are summarized in the monographies by Martínek et al. (1984), Hunter (1988), Uhrín (1992), Pivko (1995). Structural changes in the oviduct were described in detail during estrus in cows (Uhrín 1992), during puerperium in sheep (Krajničáková 1998) and in rabbit (Massanyi 1996). Macroscopic and biometric

Address for correspondence:

MVDr. Mária Krajničáková, CSc.

Research Institute of Veterinary Medicine,
Phone: +421556332012

Fax: +421556331853

http://www.vfu.cz/acta-vet/actavet.htm 
evaluation of the uterus and oviduct in goats postpartum was reported by Krajničáková et al. (2002).

The aim of the study was to characterize the structural changes in the surface epithelium and endometrial glands as well as oviduct mucosa in goats postpartum using the light and transmission electron microscopy.

\section{Materials and Methods}

Fifteen Slovak white short-haired goats aged 2-3 years were used in the experiment. The animals were kept on a commercial farm. Feeding in winter consisted of meadow hay $(1.5 \mathrm{~kg})$, straw $(150 \mathrm{~g})$, concentrates $(250 \mathrm{~g})$ and root crops $(300 \mathrm{~g})$. Animals were fed on pasture in summer. Mineral additives containing Se, $\mathrm{Zn}, \mathrm{J}, \mathrm{Cu}, \mathrm{Co}, \mathrm{Mg}$ and water were administered ad libitum. The goats were killed $(n=3)$ on days $3,21,36$ and 40 postpartum. Immediately after bleeding, the reproductive apparatus was excised and its biometric parameters (weight, length) were evaluated. The oviduct samples were collected from the ampullary part and from uterine horns from the caruncular and intracaruncular region. The collected samples for electron microscopy were fixed by immersion in $3 \%$ glutaraldehyde and postfixed in $2 \% \mathrm{OsO}_{4}$ in a $0.15 \mathrm{M}$ phosphate buffer ( $\mathrm{pH} 7.2$ - 7.4). The specimens obtained were dehydrated and embedded in Durcupan ACM (Fluka). Ultrathin sections were contrasted with uranyl acetate and lead citrate (Reynolds 1963) and photographed using the electron microscope TESLA BS 500. Semithin sections were stained with toluidin blue and photographed by the microscope OLYMPUS CH2.

\section{Results}

Evaluation of semithin sections from the endometrium (Plate V, Fig. 1) (caruncular region) revealed the impairment of epithelial cells on day 3 postpartum. Some epithelial cells degenerated and their elimination was due to macrophages found in the epithelium and in the connective tissue of endometrium. Uterine glands (Fig. 2) were well developed and consisted of cells arranged in the pseudostratified columnar epithelium. Basal membrane was undamaged and microvilli were found on its apical part. Lymphocytes and neutrophil granulocytes were observed in the lumen of uterine glands.

Pseudostratified columnar epithelium was found on the semithin sections from the ampullary part of oviducts on day 3 postpartum (Plate VI, Fig. 3). It contained mostly ciliated cells and sporadic secretory cells that were released into the lumen. Macrophages were found under the basal membrane in the connective tissue.

Examination with the electron microscope (Fig. 4) revealed the presence of numerous kinocilia on the free border. Numerous mitochondria and cisternae of endoplasmic reticulum were found in the cytoplasm. A secretory cell with a small number of secretory granules extended into the lumen. Sporadic short microvilli were present on their surface and cisternae of the endoplasmic reticulum were well developed. Well developed basal corpuscles were found under the basis of kinocilia. Individual cells are connected with numerous interdigitations and firm intercellular connections of the type zonule occludens.

On day 21 of the postpartum period, impaired cells with vacuolised cytoplasm were observed on the ultrathin sections from the caruncular region of the uterus. Mitotic cells occurred close to the basal membrane (Plate VII, Fig. 5). The basal membrane was continuous without any signs of damage. Uterine glands were in the stage of proliferation (Fig. 6). The cells contained a number of cisternae of the granulated endoplasmic reticulum.

The ultrathin sections from day 21 after parturition (Plate VIII, Fig. 7) showed that secretory cells with secretory granules increased in the epithelium of the oviduct ampulla.

The uterine surface epithelium on day 36 postpartum was continuous, simple columnar and in some locations pseudostratified columnar. No signs of morphological damage to cells were found. Tall and thin cells rest on the continuous basal membrane. Sporadic intraepithelial lymphocytes were present in the epithelium on semithin sections (Fig. 8). The presence of macrophages was not increased. In the endometrium there was a high number of proliferating uterine glands that fill in most of connective tissue (Plate IX, Fig. 9). Glandular cells at different stages of mitotic division were also present. 
The presence of numerous kinocilia was observed on the free border of ciliated cells of the oviduct mucosa on day 36 postpartum (Fig. 10). Nuclei of these cells were oval with numerous invaginations of nucleus membrane. Their typical, regular arrangement in a shape of central and peripheral tubules is presented in the electron micrograph of ultrathin sections (Plate X, Fig. 11). Glandular cells contained a great amount of dense secretory granules in the cytoplasm.

The microscopic and submicroscopic appearance of the uterus and oviduct on day 40 after parturition was similar to that on day 36 of the period observed. Gradual proliferation of uterine glands in the endometrium was observed and glandular cells in the oviduct were in the course of secretion and their cytoplasm contained secretory granules of various sizes (Fig. 12).

\section{Discussion}

Both the surface epithelium of the endometrium and secretory epithelium of the endometrium glands change markedly in estrus (Maraček et al. 1984; Uhrín 1992; Massanyi 1996).

Detailed morphological studies on the ewe uterus during pueprerium were carried out by Van Wyk et al. (1972), Krajničáková et al. (1999) and on the epithelium of the oviduct ampulla by Cigánková et al. (1996), in the fallopian tube in women and other animal species by Jirsová et al. (1973, 1974), Martínek et al. (1984).

Analysis of the endometrium on day 3 postpartum in goats showed impaired epithelial cells. Similar findings in goats were reported by Greyling and Van Niekerk (1991) on day 4 postpartum. Macrophages were present in the epithelium and connective tissue of the endometrium, and in the lumen of uterine glands there were lymphocytes and neutrophil granulocytes. We assume that the presence of the aforementioned cells early after parturition is associated with increased resistance and protection against infection. Occurrence of neutrophil granulocytes and their release into lumen during first days postpartum in cows were reported by Kummer et al. (1989). The presence of the above cells in endometrium is essential for physiological course of involution of the uterus.

Ciliated cells with kinocilia and sporadic secretory cells with a small number of secretory granules were present in the epithelium from ampullary part of the oviduct on day 3 postpartum. In the cytoplasm there were cisternae of the endoplasmic reticulum with protein secretion being produced. Our results correspond with those recorded by Uhrín (1992) in cows during metestrus and diestrus. If we take into account that the transport of ovum to the oviduct ampulla is carried out by a primary function of kinocilia, as reported by Nakatani et al. (1985), Arnold and Shorey (1985), the presence of ciliated cells with kinocilia on the day observed may not be restricted to their role in fertilisation only.

Histological appearance of the endometrium from day 21 post partum documented the advancing stage of regeneration process in puerperium. Our results on the day observed are similar to those in goats on day 20 postpartum (Greyling and Van Niekerk 1991). More distinct proliferation of surface epithelium of the endometrium and uterine glands was observed by Krajničáková et al. (1999) in ewes lambed in September. Murphy et al. (1990) recorded restoration of surface and glandular epithelial cells of the endometrium in postmenopausal women after estradiol administration. Proliferation of surface and glandular epithelial cells of the endometrium is influenced by estrogens and their stimulation of the glycoprotein synthesis and secretion (Carson and Tang 1989). Regarding the data on 17 beta-estradiol concentrations during reparation processes in puerperium in ewes lambed in February (Krajničáková et al. 1990), proliferation of the goat endometrial structures after parturition correspond with the findings on day 21 of the period observed.

Although ciliated cells prevailed in the epithelium of the oviduct ampulla on day 21 
postpartum, secretory cells with secretory granules of various size and density increased. Morphological structure of epithelial cells of the oviduct in ewes postpartum reported by Cigánková et al. (1996) is in agreement with our results.

On day 36 surface epithelium of the endometrium was continuous, simple columnar and in some locations pseudostratified columnar. Tall and thin epithelial cells did not show any signs of damage. Evaluation of the morphological structure of surface epithelium of the endometrium confirms the completion of involution and reparation processes by day 36 after parturition in goats. The above results agree with biometric evaluation of postpartum in the same animals (Krajničáková et al. 2002). The cells of uterine glands were in the stage of proliferation. Sinovatz and Friess (1983) stated that the epithelium of uterine glands proliferates from the beginning of proestrus in sows. The findings of Krajničáková et al. (1999) in ewes postpartum correspond with our results.

The presence of numerous kinocilia was observed on the free border of ciliated cells of the oviduct mucosa on day 36 postpartum. Glandular cells with a great number of secretory granules in the cytoplasm prevailed. Similar histological results were recorded by Cigánková et al. (1996) on day 34 postpartum. Verhage et al. (1973) characterize secretory cells with secretory granules in the first third of estrus in bitch. Their gradual atrophy is observed in metestrus.

The presence of numerous secretory granules found on day 36 postpartum documents their increased metabolic and secretory activity as reported by Štastný (1993) in heifers. Secretory cells with large granules in the cytoplasm were also found on day 40 postpartum. Enlarging secretory granules of various size and density in the oviduct cells were described by Brenner (1976) and correspond with our results. According to our findings, proliferation of uterine glands in the endometrium on day 40 postpartum is in the stage of estral activity.

Evaluation of the morphological structure of endometrium using light and electron microscopy has confirmed continuous overlap of surface epithelium of endometrium without the signs of morphological damage of cells on day 36 postpartum. Undamaged cell ultrastructure of proliferating uterine glands has also confirmed the above fact. Ciliated cells with numerous kinocilia were present in the oviduct mucosa. Glandular cells contained a great number of secretory granules. In agreement with our findings, involution of the goat uterus was completed by day 36 postpartum.

\section{Funkčné a morfologické hodnotenie sliznice endometria vajcovodu kôz po pôrode}

Cielom tejto práce bolo štúdium štrukturálnych zmien povrchového epitelu žliaz a endometria maternice i sliznice vajcovodu kôz na úrovni svetelnej a elektrónovej mikroskopie v puerperálnom období. Do sledovania sme zaradili 15 kôz plemena slovenská biela krátkosrstá, ktoré sme odporážali v 3., 21., 36. a 40. deň po okotení. Pri hodnotení polotenkých rezov zo sliznice maternice 3. deň po pôrode sme zistili poškodenie epitelových buniek. V lumene uterinných žliaz boli prítomné lymfocyty a neutrofilné granulocyty. Polotenké rezy z ampulárnej časti vajcovodov (3. deň po pôrode) predstavujú epitel pozostávajúci prevažne $\mathrm{z}$ ciliárnych buniek a ojedinelých sekrečných buniek, ktoré odchádzali do lumenu vajcovodu. Bunky v cytoplazme obsahovali mitochondrie a cisterny endoplazmatického retikula. V karunkulárnej oblasti sliznice maternice $\mathrm{v} 21$. dni po pôrode sme pozorovali $\mathrm{v}$ ultratenkých rezoch poškodené bunky $\mathrm{s}$ vakuolizovanou cytoplazmou. Prítomné uterinné žlazy v sliznici maternice boli v štádiu proliferácie. Ultratenké rezy z 21. dňa po pôrode ukázali, že epitel vajcovodu pozostával prevažne z ciliárnych buniek a v sekrečných bunkách pribúdali sekrečné granuly. Povrchový epitel endometria na 36. deň bol súvislý, jednovrstvový cylindrický, miestami viacradový cylindrický. Zmeny morfologického poškodenia buniek sme nezistili. Na apikálnom 
povrchu ciliárnych buniek sliznice vajcovodu sme pozorovali prítomnosṫ početných kinocílií. Žlazové bunky obsahovali v cytoplazme velké množstvo denzných sekrečných granúl (36. deň po pôrode). Mikroskopický a submikroskopický obraz maternice a vajcovodu v 40. dni bol podobný ako v 36. dni po pôrode. Dosiahnuté výsledky možno využit pri synchronizácii alebo indukcii pohlavného cyklu, intenzifikácii reprodukcie a zvyšovaní reprodukčnej obrátky v chove kôz.

\section{References}

ARNOLD R, SHOREY CD 1985: Structure of the oviductal epithelium of the brush- tailed possum (Trichosurus vulpecula). J Reprod Fertil 73: 9-19

BOTHA HK 1976 in VAN NIEKERK, CH 1979: Limitation to female reproductive efficiency. In: Sheep breeding. Ed. By Tomes, GJ, Robertson, DE, Lightfoot, RJ, Butterworths London, pp.303-313

BRENNER RM 1976: Electron microscopy of estrogen effects on ciliogenesis and secretory cell growth in rhesus monkey oviduct. Anat Rec 157: 218-227

CARSON DD, TANG JP 1989: Estrogen induced N-linked glycoprotein expression by immature mouse uterine epithelial cells. Biochemistry 28: 8116-8123

CIGÁNKOVÁ V, KRAJNIČÁKOVÁ M, KOKARDOVÁ M, TOMAJKOVÁ E 1996: Morphological changes in the ewe uterine tube (oviduct) epithelium during puerperium. Vet Med - Czech 41: 339-346

GREYLING JPC, VAN NIEKERK CH 1991: Involution of the post partum uterus of the Boer goat. JS Afr Vet Assoc 62: 4-9

HUNTER RHF 1988: The fallopian tubes, their role in fertility and infertility. Springer Verlag, Berlin, New York, $191 \mathrm{p}$.

JIRSOVÁ Z, KRAUS R, MARTÍNEK J 1973: Mitochondrial variability of rat oviduct epithelium. Fol Morph Praha 21: 269-271

JIRSOVÁ Z, KRAUS R 1974: Some aspects of early differentiation of rat tubal epithelium. Fol morph Praha 22 : 222-224

KRAJNIČÁKOVÁ M, ELEČKO J, BEKEOVÁ E, MARAČEK I, HENDRICHOVSKY V 1990: Biometrické parametre maternice, vaječníkov a koncentrácie 17 beta estradiolu po pôrode oviec. Vet Med Praha 35: 747756

KRAJNIČÁKOVÁ M 1998: Vajcovod a maternica v priebehu aktívne vedeného puerpéria oviec. Monografia ÚEVM, Košice, 1-71

KRAJNIČĆKOVÁ M, BEKEOVÁ E, LENHARDT L', CIGÁNKOVÁ V, VALOCKY I, MARAČEK I 1999: Microscopic analysis of the uterine endometrium in postparturient ewes. Acta Vet Brno 68: 9-12

KRAJNIČĆKOVÁ M, KOSTECKY M, DANKO J, LENHARDT L, CIGÁNKOVÁ V, MARAČEK I $2002:$ Biometrické parametre maternice a vajcovodov po pôrode kôz. 5. košický morfologický deň s medzinárodnou účastou, máj. In: Zborník referátov, 31. máj 2002, Košice, pp. 143-144

KUMMER V, ZRALY Z, ČANDERLE I 1989: Histology of the endometrium of cows during physiological and pathological puerperium. Vet Med Praha 34: $603-612$

LYNGSET O. 1968: Studies on reproduction in the goat. 2. The genital organs of the pregnant goat. Acta Vet Scand 9: $242-252$

MARAČEK I, ELEČKO J, HAJURKA J, CHOMA J, BEKEOVÁ E, JUŠÍKOVÁ A 1984: Mikromorfológia endometria dojníc po synchronizácii ruje cloprostenolom. Vet Med Praha 29: 679-688

MARTÍNEK J, KRAUS R, JIRSOVÁ Z 1984: Funkční cytologie epitelu vejcovodu. AVICENUM Praha, 108 p.

MASSANYI, P 1996: Štrukturálne zmeny vaječníka, vajcovodu a maternice samice králika po podaní kadmia. Monografia, VŠP, Nitra. $70 \mathrm{p}$.

MURPHY CR, ROGERS PAW, KOVACS G, HAILES J, HOSIE M, BEATON L 1990: Early evaluation of postmenopausal hormonal steroid therapy by scanning electron microscopy. Acta Anat 138: 364-366

NAKATANI T, SHINDHARA H, TAKEDA K, MORISAWA S, MATSUDA T 1985: Morphology of the intercapsular segment of the oviduct in the golden hamster with special reference to ovum transit from ruptured follicles to the ampulla. Experientia 41: $368-370$

PIVKO J 1995: Morfogenéza oocytov a raných embryí niektorých živočíchov. Monografia VÚŽV, Nitra SAP, $113 \mathrm{p}$.

REYNOLDS ES 1963: The use of lead citrate at high pH as an electron opaque stain electron microscopy. J Cell Biol 17: 208-212

SINOVATZ I, FRIESS AE 1983: Uterine gland of the pig during pregnancy. Anat Embryol 166: 121 -134

SRIVASTAVA VK, PANDEY MD 1982: Observations on the ovaries and uterus in post partum goats. Proceeding of the 3rd International Conference of Goat Production and Disease. Tuscon, Arizona, United States of America, $495 \mathrm{p}$.

ŠŤASTNY P 1993: Zmeny štruktúry sliznice vajcovodu a maternice jalovíc v postpartálnom období. Acta Zootechnica, Monografia VŠP, Nitra, XLVIII: 1-50 
UHRÍN V 1992: Funkčná morfológia vajcovodu a maternice kravy. Monografia VÚŽV, Nitra: 169 p.

VAN WYK LC, VAN NIEKERK CH, BELONJE PC 1972: Involution of the post partum of the ewes. JSAfr Vet Assoc 43: 19-26

VERHAGE HG, ABEL JH, TIETZ WJ, BARRAU MD 1973: Development and maintenance of the oviductal epithelium during the oestrous cycle in the bitch. Biol Reprod 9: 460-474 
Plate V

Krajničáková M. et al.: Functional... pp. 517-522

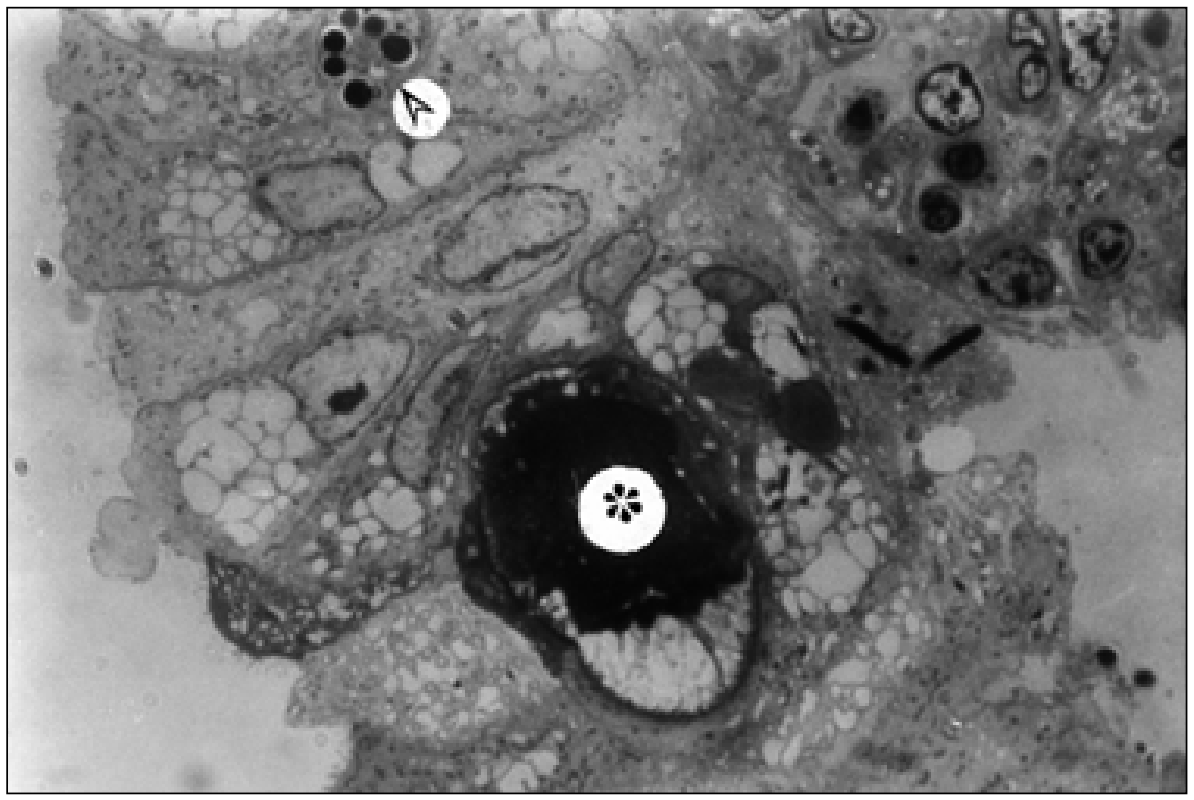

Fig. 1. Epithelium from the uterine mucosa from the caruncular region on day 3 postpartum (semithin section). Some cells degenerated (*). Macrophages take part in their removal (arrow). Magnification: $\times 1000$

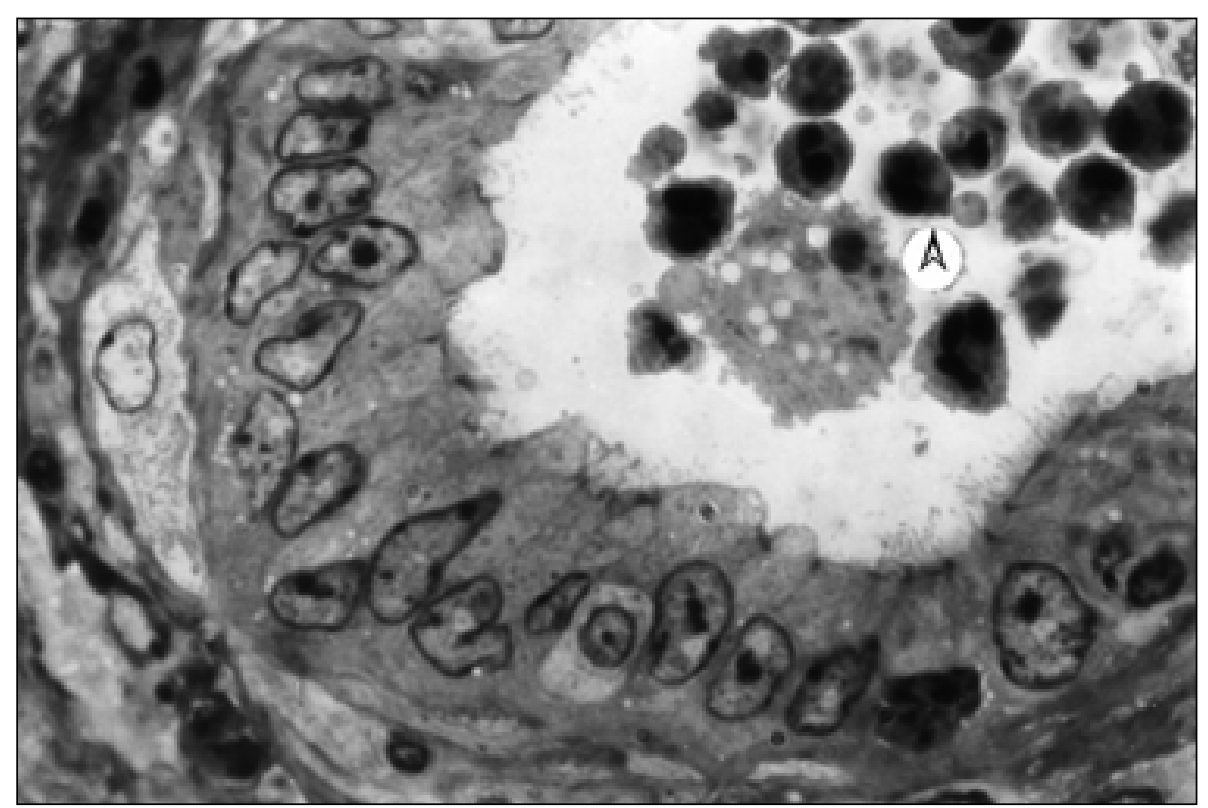

Fig. 2. Cross-section of the uterine gland on day 3 postpartum (semithin section). Neutrophil granulocytes and lymphocytes (arrow) are present in the lumen. Magnification: $\times 1000$ 
Plate VI

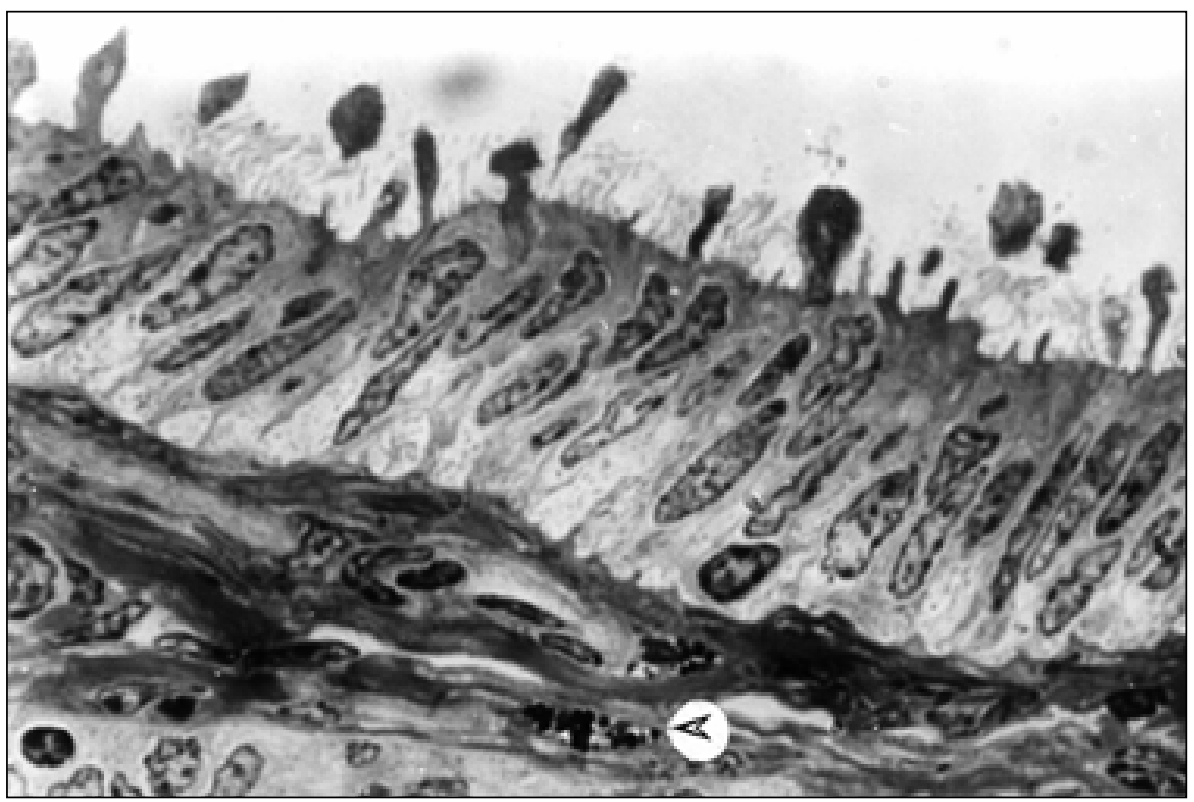

Fig. 3. Ampullary part of the oviduct on day 3 postpartum (semithin section). Epithelium contains ciliated cells, secretory cells are released into the lumen. Macrophages are present in the connective tissue (arrow). Magnification: $\times 1000$

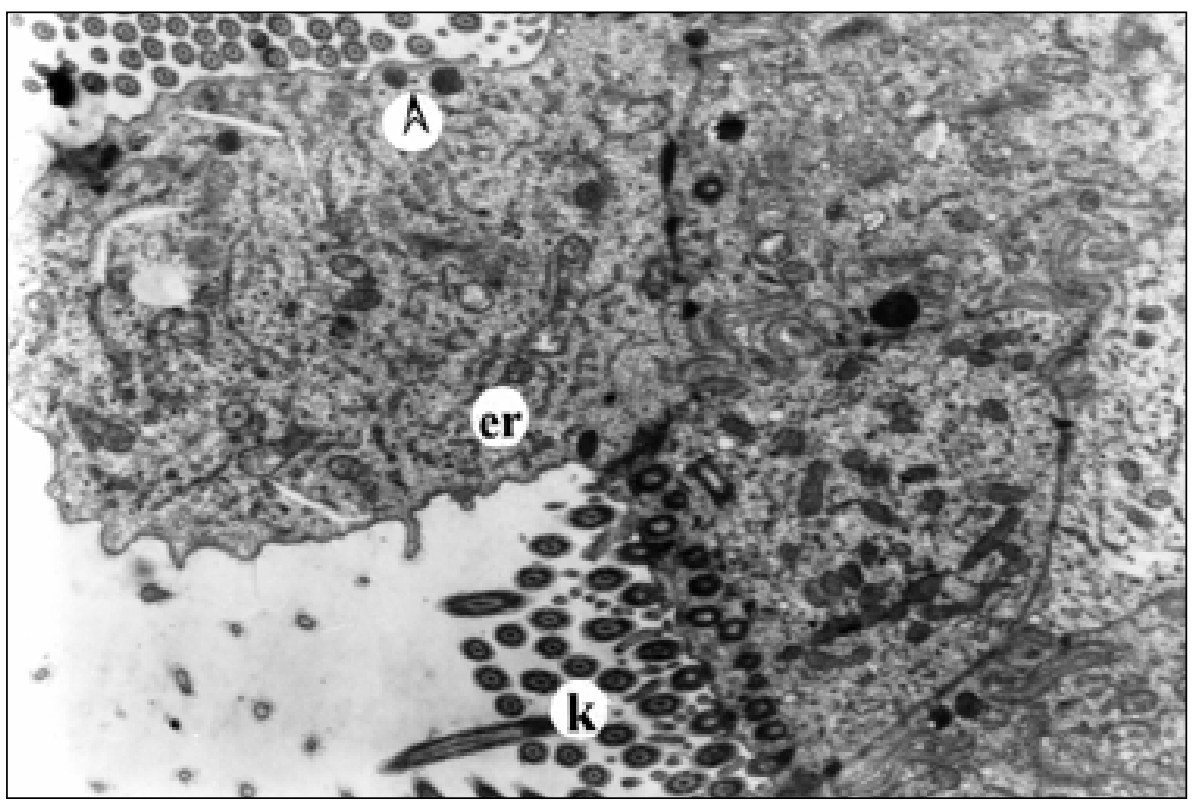

Fig. 4. The apical part of the ampullary epithelium of oviduct on day 3 postpartum. Numerous kinocilia $(\mathrm{k})$ are on the surface of ciliated cells. A secretory cell extends into the lumen with a small number of secretory granules (arrow). Low microvilli with well developed cisternae of the endoplasmic reticulum (er). Magnification: $\times 12000$ 
Plate VII

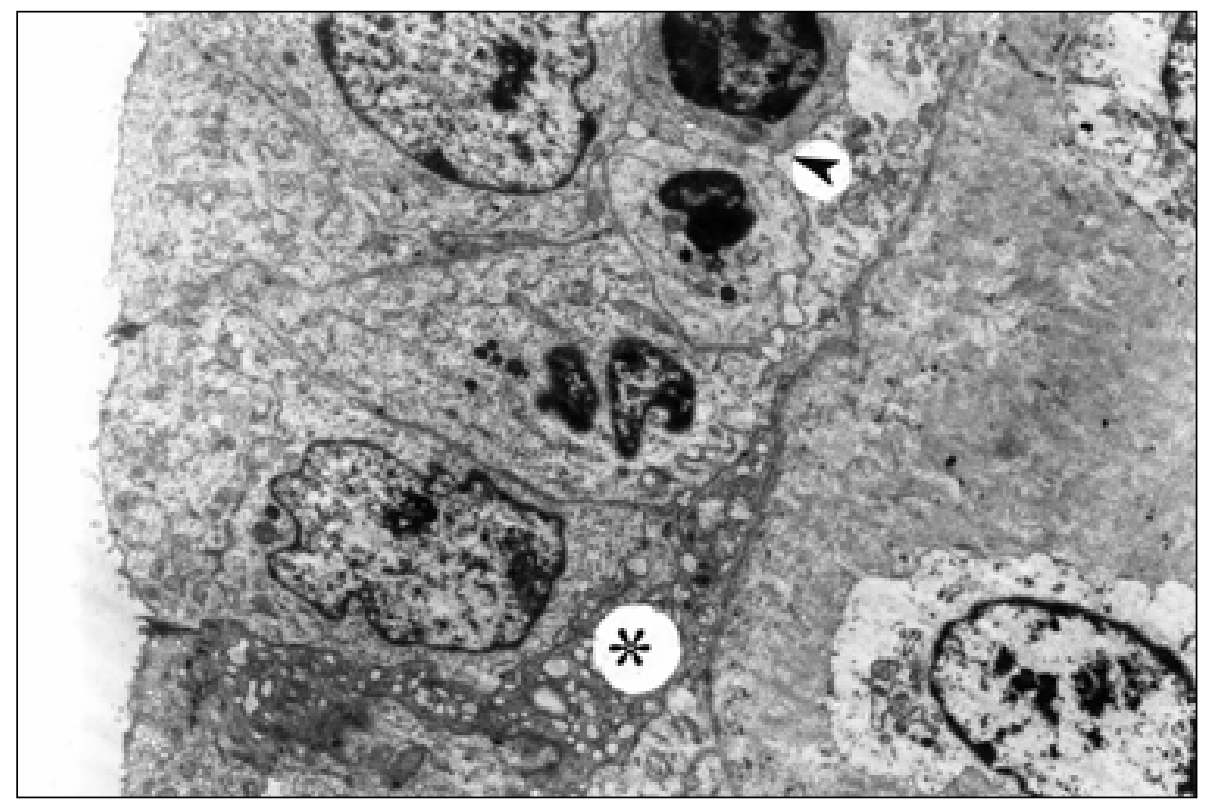

Fig. 5. The uterine epithelium from caruncular region on day 20 postpartum. Impaired epithelial cells have a vacuolised cytoplasm (*). Mitotic cells are close to basal membrane. Magnification: $\times 8000$

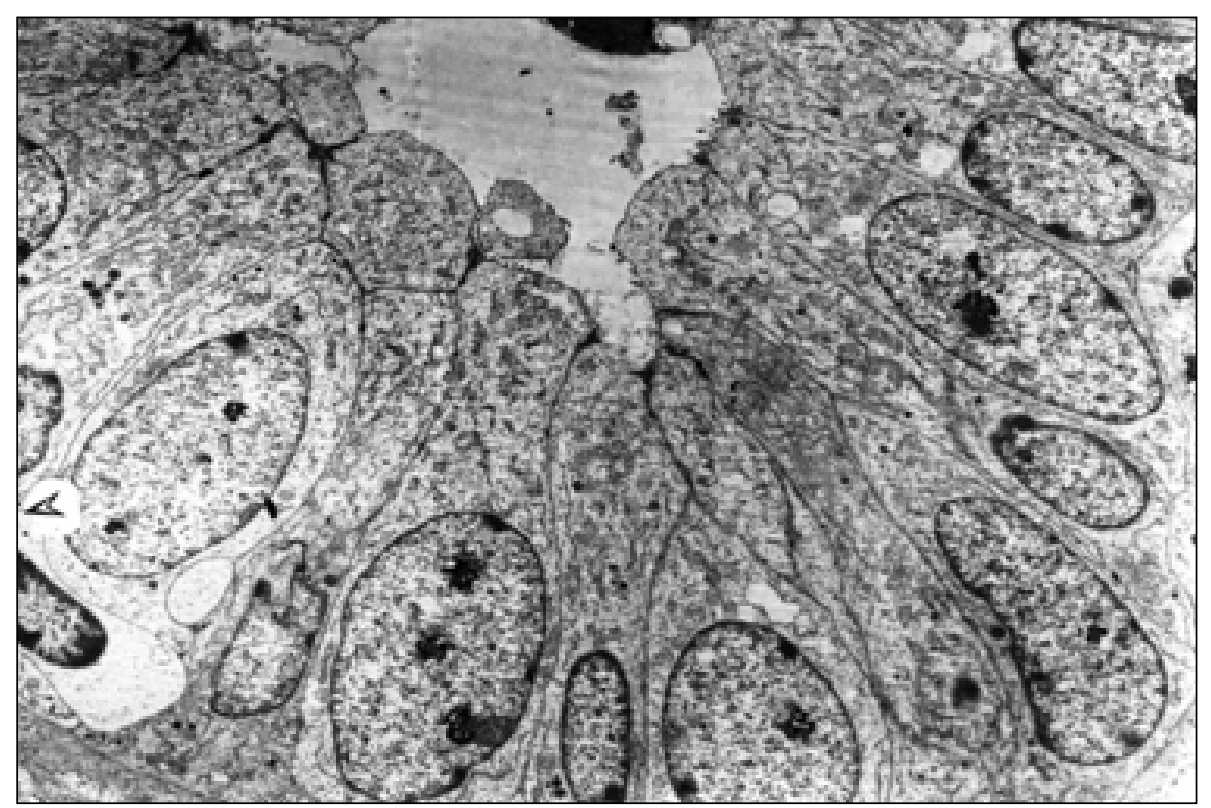

Fig. 6. The uterine gland on day 21 postpartum in the stage of proliferation. Mitosis of glandular cells close to basal membrane (arrow). Magnification: $\times 8000$ 
Plate VIII

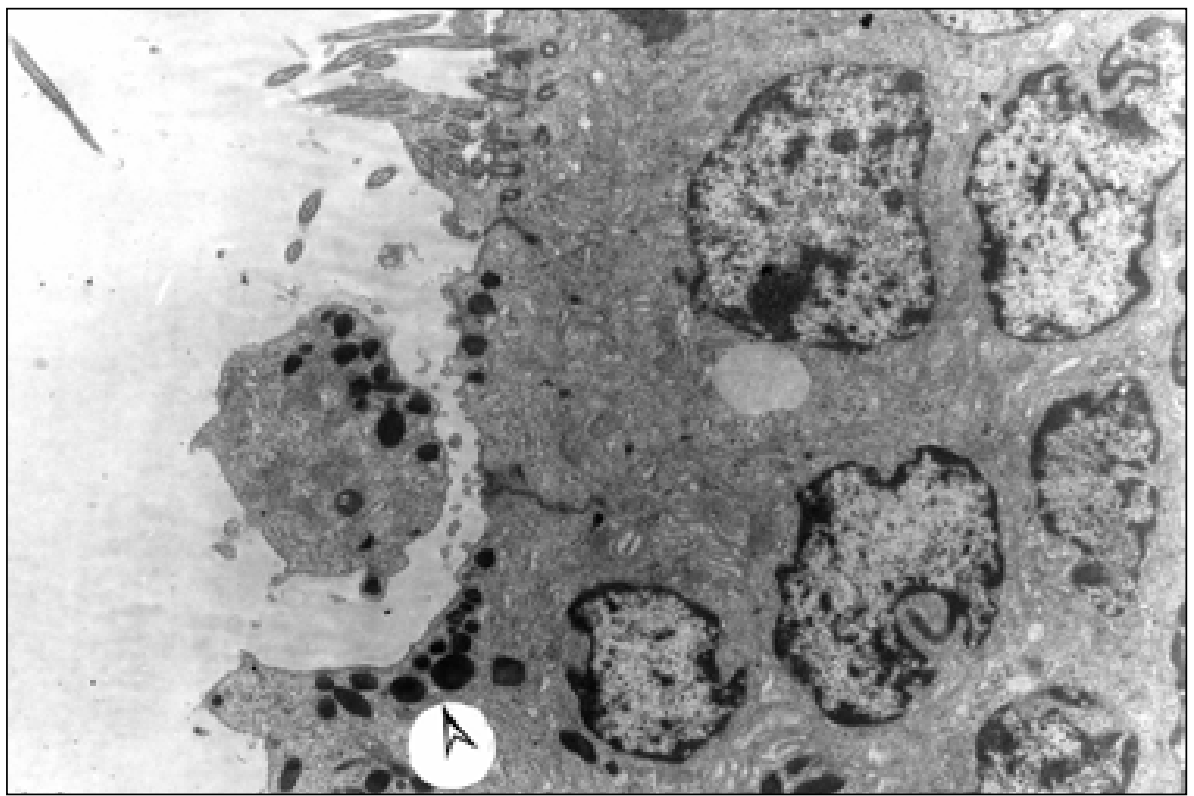

Fig. 7. The epithelium of the oviduct ampulla. Epithelium contains ciliated and secretory cells with secretory granules in the cytoplasm (arrow). Magnification: $\times 10000$

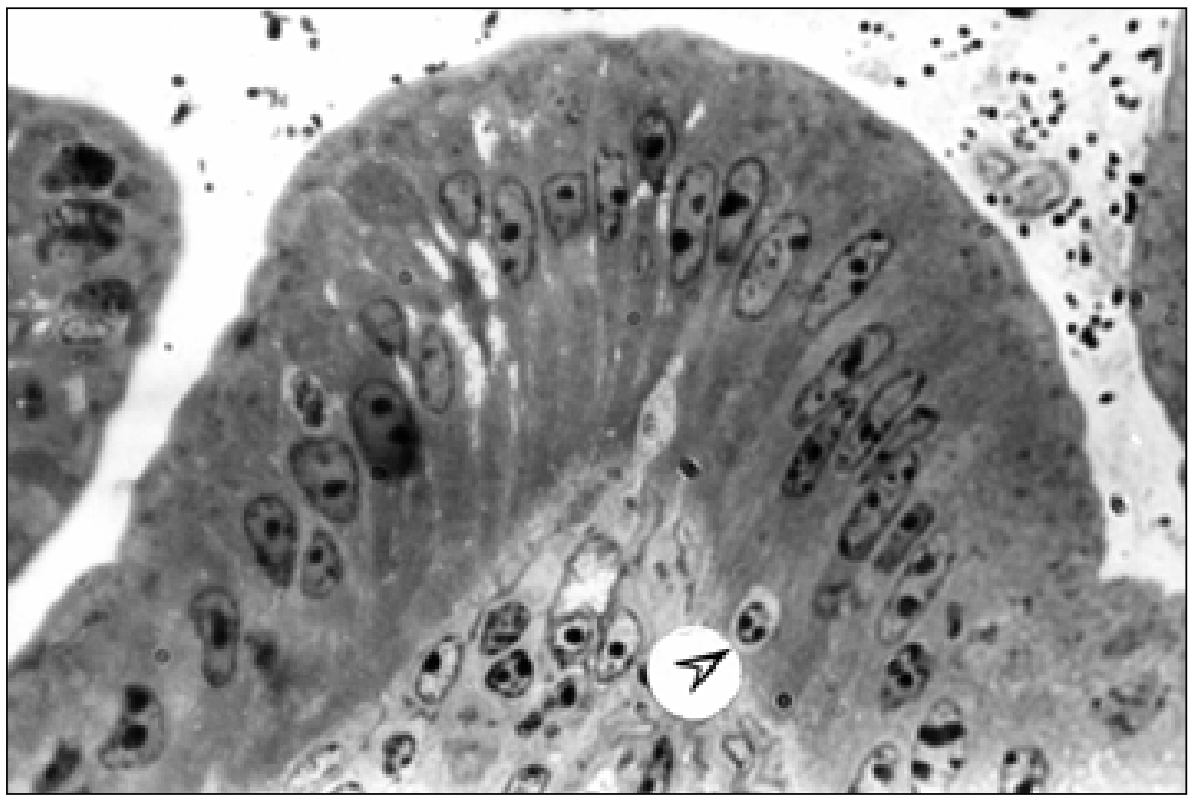

Fig. 8. Endometrium on day 36 postpartum (semithin section). Surface epithelium is simple columnar, tall, thin cells rest on continuous basal membrane. Sporadic intraepithelial lymphocytes are present (arrow). Magnification: $\times 1000$ 
Plate IX

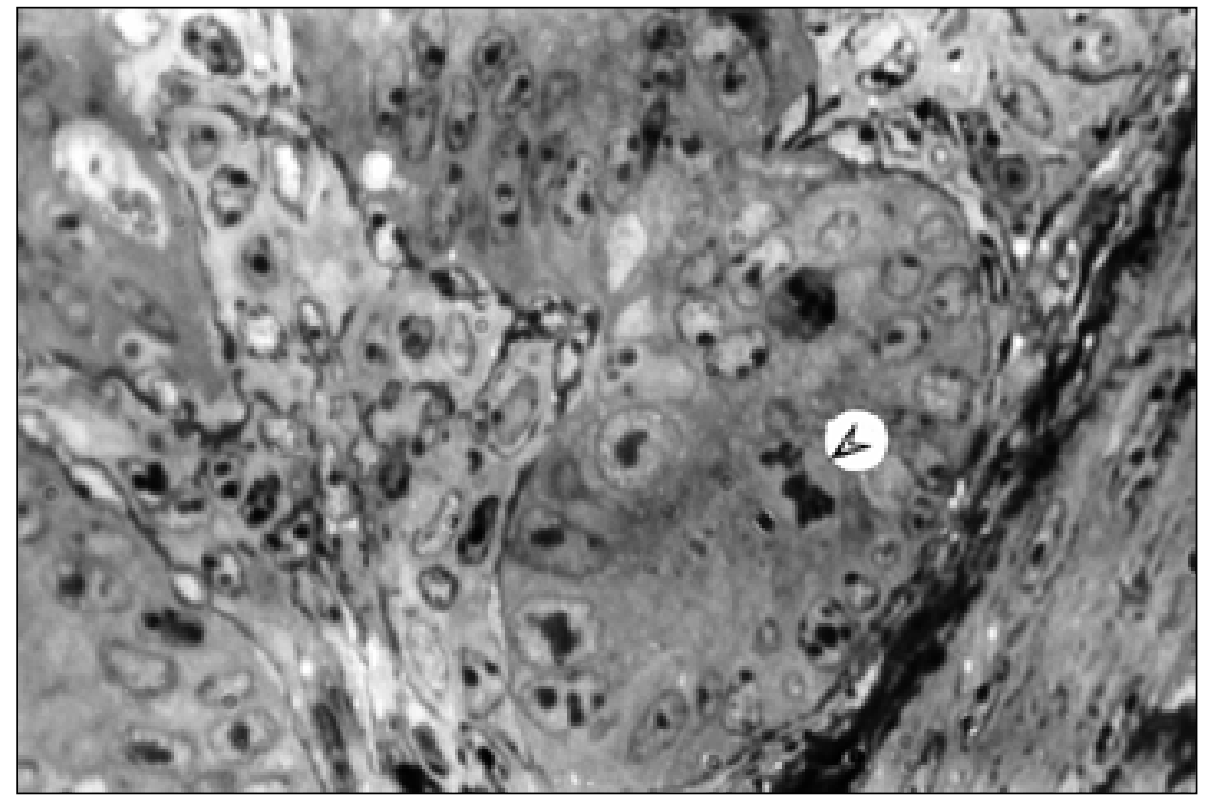

Fig. 9. Endometrium with the uterine glands on day 36 postpartum (semithin section). Glands are in the stage of proliferation and consist of cells in different stages of mitotic division (arrow). Magnification: $\times 1000$

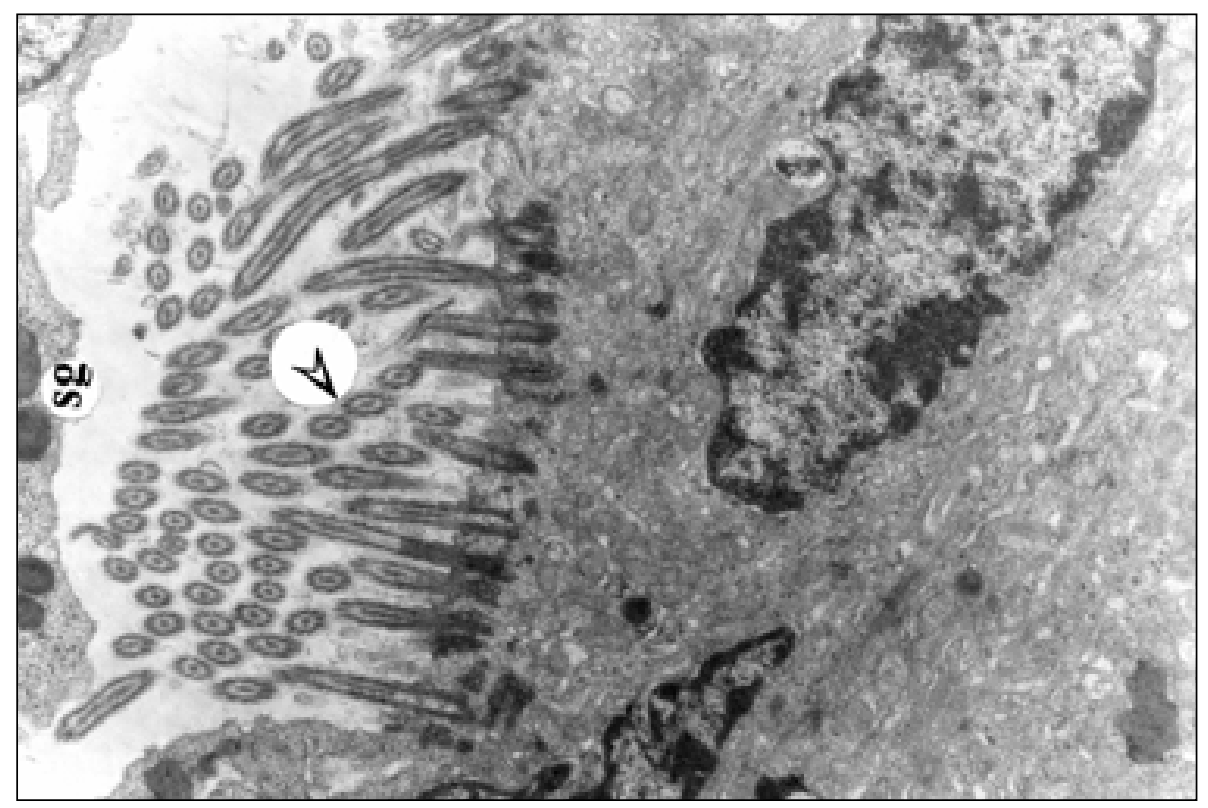

Fig. 10. The oviduct mucosa on day 36 postpartum. Numerous kinocilia (arrow) are present on the free border of ciliated cells. Secretory cells contain a great number of secretory granules (sg) in the cytoplasm. Magnification: 12000 
Plate X

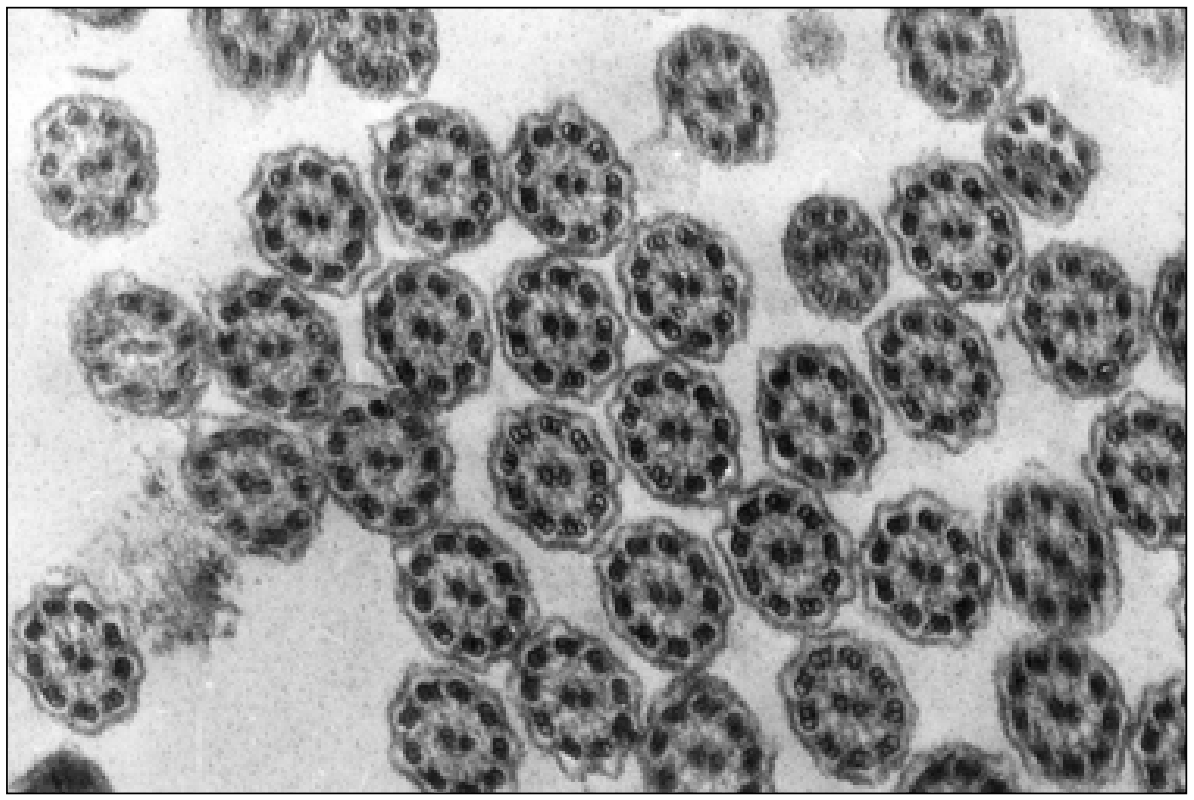

Fig. 11. The kinocilia from the oviduct on a cross-section with a typical regular arrangement of central and peripheral tubules. Magnification: $\times 24500$

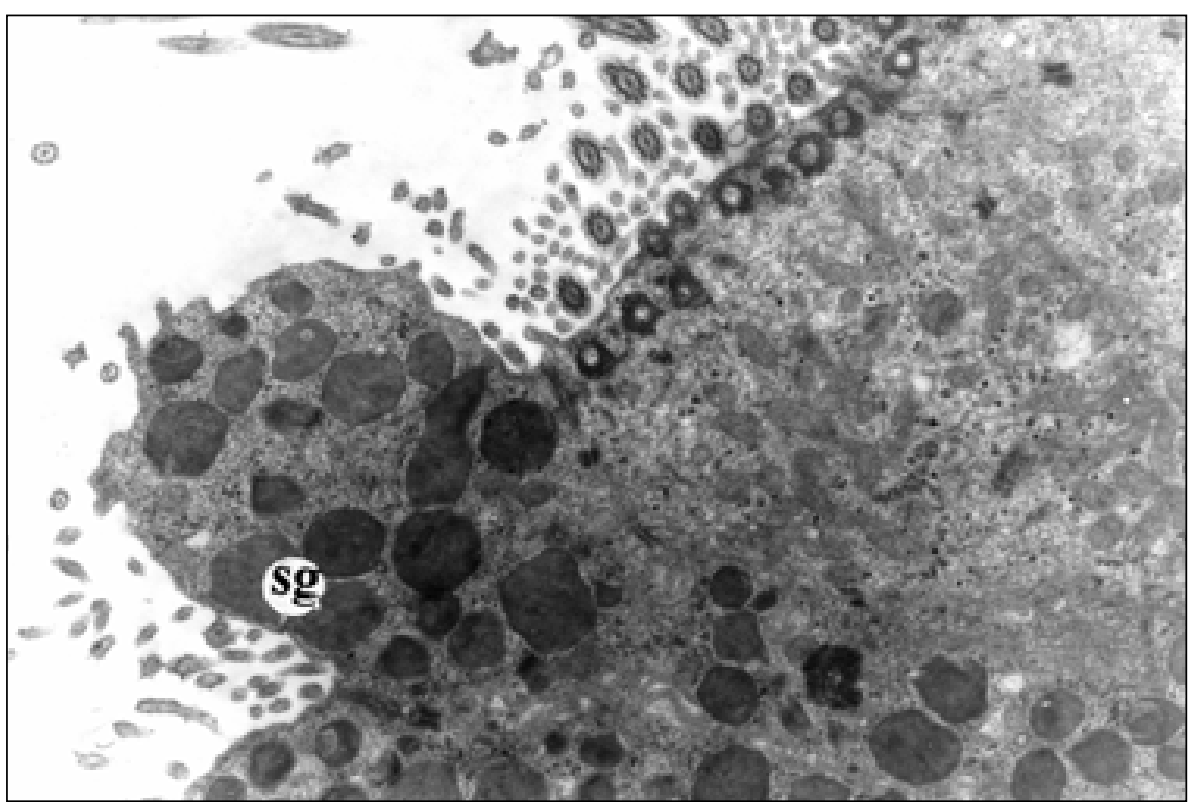

Fig. 12. The apical part of oviduct ampulla on day 40 postpartum. Secretory cells contained large secretory granules of spherical shapes, different size and density (sg) in the cytoplasm. Magnification: $\times 12000$ 